\title{
Effects of demographic factors on intention for self- employment among postgraduate students of Abubakar Tafawa Balewa University, Bauchi-Nigeria
}

\author{
By \\ Shehu Rabiah Na-Allah', Mangai Josiah Mallo², \\ Patrick Bogoro ${ }^{3} \&$ Adamu Jibir $^{4}$ \\ ${ }^{1,4}$ Gombe State University, Gombe-Nigeria \\ ${ }^{2,3}$ Abubakar Tafawa Balewa University, Bauchi-Nigeria
}

\begin{abstract}
High unemployment rate among Nigerian graduates has been the issue of concern to both government and concerned stakeholders in the quest of finding alternative solution to the problem. So the federal government enacted policies and programmes with mandate of providing support to address these problems. Policy trusts like Small and Medium Enterprise Agency of Nigeria, Youth Empowerment Support, Bank of Industry, Bank of Agriculture, Graduate Entrepreneurship Programme, Industrial Training Fund, Youths Enterprise Scheme, etc. were established by various administrations overtime. Yet the search for paid job among graduates still persist. It was against this background that this study examines the effect of demographic factors on intention for self-employment among postgraduate students of Abubakar Tafawa Balewa University, Bauchi-Nigeria. The students cut across six faculties of Engineering, Science, Agriculture, Management, Environmental and Education. Crosssectional survey research design was used in which 311 questionnaires were administered to respondents using proportionate stratified sampling technique. 309 questionnaires were returned, 5 discarded as outliers and 304 were due for data analysis. The data was analyzed using IBM SPSS software version 23.0. Age, was analyzed using univariate analysis and analysis of variance (ANOVA), while gender was analyzed using independent samples t-test analysis. Finding of the study reveals gender as a significant factor on intention for selfemployment with males possessing higher intention than females' counterparts. Therefore, universities should complement government effort by channeling entrepreneurial support to postgraduate students on the basis of gender. Universities should even replicate world-class practice by establishing an innovation-lab where future student-entrepreneurs can be trained early on skills acquisition programmes. This will help reduce graduates' unemployment and bringing about productivity for growth and development of the economy.
\end{abstract}

Keywords: Demographic factors, Self-employment, Postgraduate student 


\subsection{Introduction}

The Nigerian economy has enormous business and investment potentials that confer it basis for entrepreneurship opportunities. This is due to abundant, vibrant and dynamic human and natural resources it possesses. Self-employment is very prominent and widely practiced across the globe. Its operation is commonly practice by sole-traders, partnership ventures, franchise contracts and corporations. This practice has covered wide range of geography linking trade from Asia to America, Eastern Pacific to Europe, and Africa to Latin America (WTO, 1996). Some of its specific benefit has impacted in many aspects of human and economic endeavors in the areas of agriculture, mining, education, health, energy, manufacturing, transport, techn ology, communication, tourism, sports, entertainment, etc. to mention a few.

At the onset, the Nigerian government's core objective drives towards promoting selfreliance in every facet of life. This is because the present condition of employment is no longer automatic for graduates beyond available vacancies in both public and private works of life. This is due to increased proliferation in number of graduates produced annually from various institutions of learning seeking for job. So its high time these graduates find a way of becoming creative, innovative and self-reliant to surmount these unemployment problems (Johnson, 2017). Dandago \& Muhammad (2014) affirmed that this issue contributed to the current unemployment rate with entrepreneurship seen as one-way out of this challenge. So government over time initiated programs that can help boost entrepreneur ship for the teeming graduates. Schemes like the National Directorate of Employment (NDE), Small and Medium Enterprise Development Agency of Nigeria (SMEDAN), Bank of Agriculture (BOA), Bank of Industry (BOI), Youths Empowerment Scheme etc. were introduced to meet up to this challenge in the provision of self-employment opportunities. But even with this development, unemployment among graduates still persist. This is why Mubbsher, Ishfaq, Muhammad \& Muhammad (2011) opined that one of the most effective alternatives capable of sustaining self-reliance as suggested by the economists is self-employment.

Self-employment can be seen as comprising desirable state chosen reluctantly by individuals unable to find appropriate paid job under current labour market conditions (Dawson, Henley \& Latreille, 2009). Accordingly, Kim (2008) viewed self-employment as an important source of new jobs and an alternative to paid employment. As it grows, the given economy and other social institutions develop. That's why individuals may choose to be selfemployed for many different reasons because it drives the economy towards competitive market orientation than salaried job does (Dawson et al. 2009). But selfemployment on its own is not a function that might be an outcome of simple efforts. It requires regular and permanent attitude as part of individuals intending to venture into 
self-businesses. Attitudes of individuals can be based on personality traits and demographic characteristics; it can also be reshaped with education to smoothen the selfemployment process (Mubbsher et al. 2011). Among these characteristics are demographic factors such as age, gender, marital status, race, level of education, prior experience, income and occupation (Leong, 2008; Johnson, 2016) that stimulate individuals towards a desirable action. Most researches acknowledge the fact that Ajzen's theory of Planned Behavior (TPB) is fit enough to explain individual's intention towards a behavior (Okoye, 2016).

This study centered on postgraduate students of Abubakar Tafawa Balewa University (ATBU) located in North-Eastern Bauchi state of Nigeria. The institution since inception in the 1980's had been running both undergraduate and postgraduate programs in six faculties of Science, Engineering, Agriculture, Management Sciences, Environmental and Technology Education (Academic Brief Report, 2014). For instance, the school of postgraduate studies (SPGS) came into being during the $1995 / 1996$ academic session with the objective of providing graduates with skills and attitudes that will enable them to become self-reliant (SPGS, ATBU, 2017).

So prior to understanding that studies related to investigating PG student's intention for self-employment has not been done in ATBU, and to complement the objective of SPGS informed the quest for this study. Therefore, it was against this background that this study examines the effect of age and gender on intention for selfemployment PG students of ATBU BauchiNigeria.

\subsection{Objectives of the study}

The objective of the study is to determine the "effects of demographic factors on intention for self-employment among postgraduate students of ATBU Bauchi-Nigeria". Other specific objectives of the study are to:

i. Examine the effect of gender on intention for self-employment among postgraduate students of ATBU Bauchi.

ii. Examine the effect of age groups on intention for self-employment among postgraduate students of ATBU Bauchi.

\subsection{Hypotheses of the study}

The following hypotheses were formulated to guide the study: -

$\mathrm{HO}_{1}$ : Gender has no significant effect on intention for self-employment among postgraduate students of ATBU Bauchi. $\mathrm{HO}_{2}$ : Age group has no significant effect on intention for self-employment among postgraduate students of ATBU Bauchi.

\subsection{Literature review}

\subsection{Intention for self-employment}

Self-employment may comprise a far less desirable state chosen reluctantly by individuals unable to find appropriate paid employment under current labour market conditions (Dawson et al. 2009). Individuals or graduates wanting flexible working hours 
might choose self-employment if a paid employment contract offering sufficient flexibility is unavailable. This is because entrepreneurship has been the driving force behind most nations' economic progress and development. Thus, the interest towards entrepreneurship receiving increased attention and sustained interest would appear to be more than just a fad (Vijeyan, ShishiKumar, Abd Kadir, \& Zahir, 2015). At the same time, even as self-employment continues gaining acceptance globally, policymakers are reluctant of this trend as an opportunity for addressing enduring joblessness (Goetz, Fleming, \& Rupasingha, 2012).

Basically, youths are seen as potential business leaders and basis upon which future economic growth and development of every society will depends. An increase in the number of these youths in tertiary institutions is a positive development (Agbim et al. 2013). As a result, there has been a great concern among education stakeholders about how university education could meet the need of the youths through entrepreneurship acquisition in Nigeria, (Sofoluwe, as cited in Ogundele, Sofoluwe \& Kayode, 2012). Amoor (2008) argues that incorporating entrepreneurial education into universities curriculum will equip students with vast knowledge and creative abilities to initiate businesses that will significantly contribute to the nation's economic growth and development. Ayuo \& Kubasu (2014) observed that most researches in literature are conducted in developed nations where establishing a business and finding a formal employment is easier as compared to developing economies like Kenya, Nigeria, Ghana, etc. In these countries, only few formal employment opportunities exist with many qualified university graduates competing for few positions.

\subsection{Demographic factors}

Demographic factors are personal characteristics used to collect and evaluate data on people in a given population. Typical factors capable of stimulating individual's intention for self-employment include age, gender, marital status, race, level of education, prior experience, income and occupation (Johnson, 2016; Agbim et al. 2013; Ismail, Khalid, Othman, Jusoff, Rahman, Kassim, \& Zain, 2009; Leong, 2008). Researches attributed the facts that demographic factors and their variation in the business environment are the most important factors that explain entrepre neurial choice (Okoye, 2016; Ayuo \& Kubasu, 2014; Agbim et al., 2013; Mubbsher et al. 2011).

\subsection{Review of empirical studies}

The study of Ayuo \& Kubasu (2014) reveals that attitudes and contextual factors such as gender and family background were found to be significant contributors to entrepreneurial intention. Similarly, Majogoro \& Mgabo (2012) testing self-employment intention of university students in Tanzania founds that female students have higher intention towards self-reliance than male counterparts. In his study, Dugassa (2012) observed that 
male management students have higher personal attraction towards entrepreneurial career, subjective norms, self-efficacy and achievement need than female management and engineering students with lower instrumental readiness on entrepreneurial intention. In similar instance, Verheul, Thuirk $\&$ Grilo (2006) founds the moderating effect of gender as an important attribute for women on lower self-employment preference. While Agbim et al. (2013) discovered gender and age as triggers of entrepreneurial intention with males indicating higher interest than female counterparts. Helena \& Maciera (2009) revealed that self-employed tend to be more men and age between 45-64, married with a small households and with low level of education. The result supports findings of Agbim et al. (2013). In their study, Perera et al. (2011) founds that gender was also significant in determining entrepreneurial intention. While Leong (2008) in an empirical study founds male students showing significantly higher intention than their opposite gender. Unlike Olawale (2014) and Ismail et al. (2009) assessing entrepreneurial intention of undergraduate students and found that majority females have higher intention than their male colleagues. Mubbsher et al. (2011) on their part examining two individual's personality traits as predictors of entrepreneurial intention found a strong relationship between demographic traits and entrepreneurial intentions.

\subsection{Theory of planned behavior}

According to the theory of planned behavior
(TPB), Ajzen (1991) explained that human behavior is guided by three kinds of considerations: beliefs about the likely consequences of the behavior (behavioral beliefs), beliefs about the normative expectations of others (normative beliefs), and beliefs about the presence of factors that may facilitate or impede performance of the behavior (control beliefs). In their respective aggregates, behavioral beliefs produce a favorable or unfavorable attitude toward the behavior; normative beliefs result in perceived social pressure or subjective norm; and control beliefs give rise to perceived behavioral control. Okoye (2016) attested that intention is assumed to be the immediate antecedent of behavior. So TPB was utilized to underpin this study because its dealing with human attitude towards a likely action (intention).

\subsection{Methodology}

This study is based on cross-sectional sample survey data that was collected at a single time. The data obtained were collected at one point in time from the selected sample. The survey data was obtained by primary source through the administration of questionnaire administered personally and with the aid of research assistants. The data obtained from their responses was analyzed using Statistical Package for Social Science (IBM SPSS Statistics, version 23.00) software to report findings. This software was also utilized during the Exploratory Factor Analysis (EFA) to determine the construct's composite reliability and dimensionality of 
the scales as satisfied by experts in research (Olawale, 2014; Hair et al. 2010; Hair et al. 2006; Pallant 2001; Fornell \& Larcker, 1981). While, IBM SPSS AMOS version 20.0 was used to conduct the Confirmatory Factor Analysis (CFA) for construct validity and unidimensionality of the measurement in line with satisfactory thresholds stipulated by experts (Ghasemi \& Zahedias, 2012; Tabachnick \& Fidell, 2007; Polit \& Beck, 2006). AMOS (Analysis of a Moment Structures) was used because according to Statistics Solutions (2017), it is an added SPSS module specifically designed for Structural Equation Modeling (SEM) and Confirmatory Factor Analysis. The validity and reliability of the measurement were equally determined as seen in table 1 below.

Table 1: Exploratory Factor Analysis (EFA)

\begin{tabular}{|c|c|c|c|c|}
\hline Construct & Items & $\begin{array}{l}\text { Factor } \\
\text { Loadi } \\
\text { ng } \\
\text { (EFA) }\end{array}$ & $\begin{array}{l}\text { Cronbac } \\
\text { h's } \\
\text { Alpha }\end{array}$ & AVE \\
\hline INTENTI & Intenti & 0.747 & 0.729 & 55.629 \\
\hline \multirow[t]{4}{*}{$\mathrm{ON}$} & on 2 & & & $\%$ \\
\hline & $\begin{array}{l}\text { Intenti } \\
\text { on } 4\end{array}$ & 0.728 & & \\
\hline & $\begin{array}{l}\text { Intenti } \\
\text { on } 6\end{array}$ & 0.748 & & \\
\hline & $\begin{array}{l}\text { Intenti } \\
\text { on } 5\end{array}$ & 0.760 & & \\
\hline
\end{tabular}

Source: SPSS Output (2017)
The reliability of the construct as seen above was obtained using the cronbach's alpha and was found to meet the minimum standard for research as suggested by (Cortina, 1993).

\subsection{Research population}

The population of this study is made up of all registered postgraduate students of the 2016/2017 academic session drawn from six faculties (Science, Engineering Technology, Agricultural Technology, Environmental Technology, Management Sciences and Technology Education) where the respondents domiciles. The total number of registered PG students currently stood at 1403 (SPGS, ATBU, 2017).

\subsection{Sample size and sampling technique}

The sample size was determined using Yamane statistical formula. The size after computation was 311 .

\section{Sampling technique}

Proportionate stratified sampling technique was used to sample participants for the study. This method was purposely employed to ensure that the sample obtained through a stratum represent elements of the population under study.

The proportionate allocation of questionnaire to the stratified faculties where the PG students' domiciles is displayed below on table 2 below. 
Table 2: Sample size by faculties

\begin{tabular}{lccc}
\hline Faculty & $\begin{array}{c}\text { Popu } \\
\text { lation }\end{array}$ & $\begin{array}{c}\text { Proportion of } \\
\text { Sample Size }\end{array}$ & $\begin{array}{c}\text { Percentage of the } \\
\text { Population (\%) }\end{array}$ \\
\hline $\begin{array}{l}\text { Agricul } \\
\text { ture }\end{array}$ & 94 & 21 & 7 \\
$\begin{array}{l}\text { Engine } \\
\text { ering }\end{array}$ & 174 & 39 & 12 \\
Enviro & & & \\
nmenta & & & 26 \\
1 & 367 & 81 & 25 \\
Manag & & & 19 \\
ement & 350 & 78 & 11 \\
Science & 265 & 59 & 100 \\
Educati & & & \\
on & 153 & 34 & \\
\hline Total & 1403 & 311 & \\
\hline
\end{tabular}

Source: SPSS Output (2017)

\subsection{Measurement of variables}

Adapted survey questionnaire was used to collect data from the study sample. It was divided into two sections with demographic section adapted from Agbim et al. (2013) and Mubbsher et al. (2011). And intention for self-employment adapted from Olawale (2014) and measured on five-point likert scale from Strongly Disagree (1) to Strongly Agree (5).

\subsection{Methods of data analysis}

Analysis of Variance (ANOVA) was used to analyzed age, while gender was analyzed with independent samples test (t-test) using SPSS Statistics 23.0.

\subsection{Results and discussion}

A total of 311 questionnaires was distributed and 309 were retrieved. Data screening was carried out on 309 out of which 304 were found to have been correctly filled. The analysis was based on 304 correctly filled and returned questionnaires. A summary of the response rate can be seen in table 3

Table 3: Summary of Response Rate

\begin{tabular}{ll}
\hline Questionnaire Items & Number \\
\hline Administered & 311 \\
Not retumed & 2 \\
Outliers & 5 \\
Valid Instruments & 304 \\
\hline
\end{tabular}

Source: Field Survey (2017)

\subsection{Data coding and examination}

Out of the 311 questionnaires administered, only 304 were dully filled and set for analysis. Few missing values were traced below 5\% (13 cases) and were replaced using mean substitution method. This replacement method is in line with Hair et al., (2010) and Tabachnick \& Fidell (2007). Errors were also checked with the aid of the software. However, two questionnaires were not returned, and five extreme outliers were detected and deleted from the dataset. This bring the total number of questionnaire to 304 as valid instruments for analysis.

Items of Intention1, Intention3, and Intention7 were deleted due to low factor loading and communality values. This brings the number of items retained to four (Intention 2,4,5\&6) 


\subsection{Descriptive analysis}

Table 5 reveals that majority of the respondents of this study were aged 31-40 years old, representing $49.7 \%$ (151) of the total respondents. While 20-30 years' age groups represent $27.0 \%$ (82) of the total respondents. Age group of 41-50 years represents $22.0 \%$ (67) of the total respondents, and 51 years and above represent $1.3 \%$ (4) of the total respondents of the study.

Majority $73.7 \%$ (224) of the respondents were male, while $26.3 \%$ (80) were female. This implies that more males than females participated in the study. Concerning marital status, majority $76.0 \%$ (231) of the respondents were married as $23.0 \%$ (70) of the participants were single, $0.7 \%$ (2) of the respondents are divorced and just $0.3 \%$ (1) respondents was a widow.

With regards to level of education, majority $65.1 \%$ (198) of the participants possess first degree (B.Sc./B.Tech.) as their highest qualification, as $11.2 \%$ (34) of the respondents possess PGD as their highest qualification, $10.9 \%$ (33) of the respondents possess MBA as their highest qualification and $9.9 \%$ (30) of the respondents possess HND as their highest qualification. While the rest $3.0 \%$ (9) of the participants of the study possess MSc as their qualification. On the basis of faculty, majority $29.9 \%$ (91) of the participants were from Environmental Management Technology, as $20.1 \%$ (61) of the respondents were from Science, 19.4\% (59) of the respondents were from Management Sciences. Thus, 10.2\% (31) of the respondents were from Agriculture and Agricultural Technology, 10.2\% (31) of the respondents were from Technology Education and $10.2 \%$ (31) of the participants were from Engineering Technology.

With respect to program of study, majority $74.3 \%$ (226) of the respondents were pursuing academic master's program, as $15.1 \%$ (46) of the participants were pursuing PGD program, 7.6\% (23) of the respondents were pursuing professional masters. While the remaining $3.0 \%$ (9) of the respondents were pursuing $\mathrm{PhD}$ program.

Lastly, majority $57.9 \%$ (176) of the participants responded "Yes" with respect to undergoing entrepreneurial courses at their undergraduate studies and $42.1 \%$ (128) of the respondents replied "No" with respect to undergoing entrepreneurial courses at their undergraduate studies. This implies that most of the respondents possess a background knowledge on self-employment. 
Table 4: Description of respondent's information

\begin{tabular}{|c|c|c|c|}
\hline Variable & & Frequancy & Percentage (56) \\
\hline \multirow[t]{4}{*}{$\overline{A g}$} & $20-30$ & $\overline{\mathbf{S}}$ & 27.0 \\
\hline & $31-40$ & $1 s 1$ & 49.7 \\
\hline & $41-30$ & $6 ?$ & 220 \\
\hline & S1 \& Above & 4 & 1.3 \\
\hline \multirow[t]{2}{*}{ Geodes } & Mase & 224 & 73.7 \\
\hline & Femile & $\mathbf{s o}$ & 263 \\
\hline \multirow[t]{4}{*}{ Masial Sasos } & Singste & $x$ & 23.0 \\
\hline & Married & 231 & 36.0 \\
\hline & Dinoesed & 2 & 0.7 \\
\hline & Widombood & 1 & 0.3 \\
\hline \multirow[t]{5}{*}{ Lavel of Etecasion } & HDD & 30 & 9.9 \\
\hline & BSE_BTech & 198 & 65.1 \\
\hline & PGD & 34 & 11.2 \\
\hline & MBA & 33 & 10.9 \\
\hline & MSe. & 9 & 3.0 \\
\hline \multirow[t]{6}{*}{ Facstry } & Seieace & 61 & 20.1 \\
\hline & Engiosering & $3 !$ & 102 \\
\hline & Agrievtexse & $3 !$ & 10.2 \\
\hline & Eerizonmenesl & 91 & 29.9 \\
\hline & Masagemes: & 59 & 19.4 \\
\hline & Edecasion & 31 & 10.2 \\
\hline \multirow[t]{4}{*}{ Program } & PGD & 46 & 15.1 \\
\hline & Academic massers & 226 & 743 \\
\hline & Professioasl masers & 23 & 7.6 \\
\hline & $\mathrm{PhD}$ & 9 & 3.0 \\
\hline \multirow[t]{2}{*}{ Eescepresevcid } & Yes & 176 & 57.9 \\
\hline & No & 125 & 421 \\
\hline
\end{tabular}

Source: Field Survey (2017) 


\subsection{Test of hypothesis}

The following hypotheses were tested at 5\% level of significance and the decision rule was; if the t-value is less than the P-value, the hypothesis will be accepted and if equal or greater than the P-value, it will be rejected in the t-test analysis. While if the F-value is less than the P-value, the hypothesis will be accepted, and if equal or greater than the Pvalue, it will then be rejected in the ANOVA result. Table 5 and 6 displays the result of each analysis for age and gender respectively on intention for self-employment.

Table 5 : Independent sample $\mathrm{t}$ - test

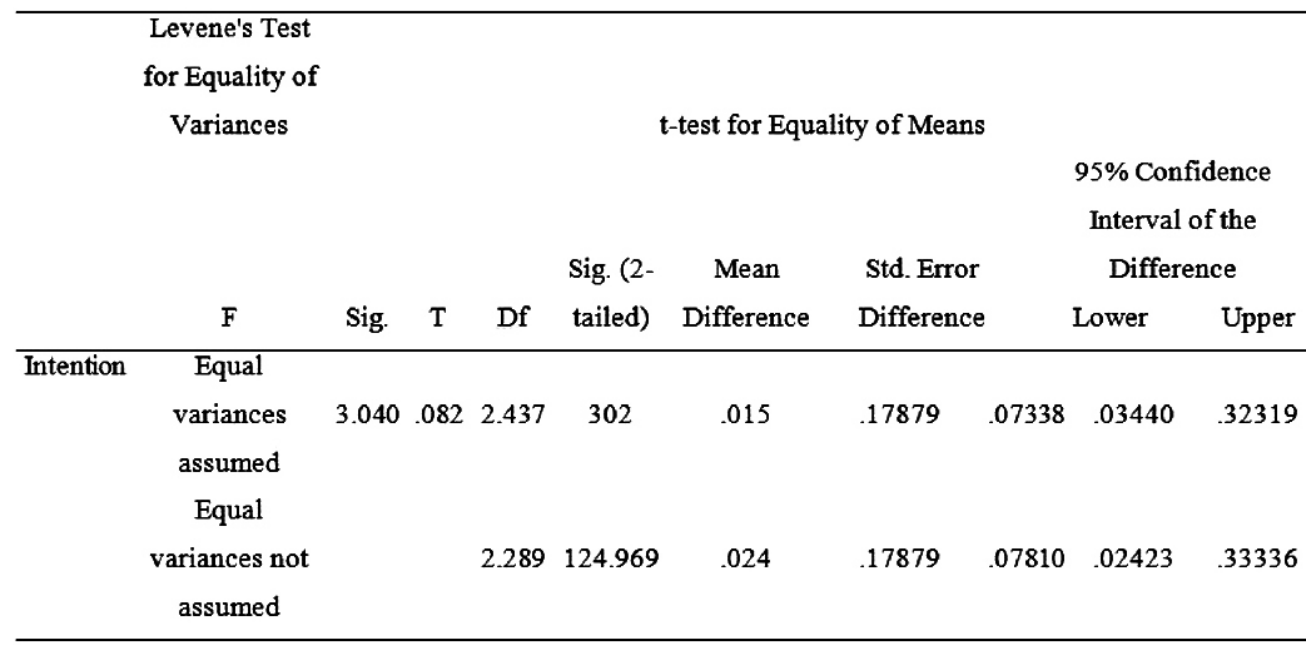

Source: Field Survey (2017)

Table 6: ANOVA Result Intention

\begin{tabular}{lccccc}
\hline & $\begin{array}{c}\text { Sum of } \\
\text { Squares }\end{array}$ & Df & Square & F & Sig. \\
\hline $\begin{array}{l}\text { Between } \\
\text { Groups }\end{array}$ & 2.453 & 3 & 0.818 & 2.574 & 0.054 \\
Within & 95.283 & 300 & 0.318 & \\
Groups & & & & \\
Total & 97.376 & 303 & & \\
& & & & & \\
\hline
\end{tabular}

Source: Field Survey (2017)

\subsection{Discussion of findings}

The t-test result as seen in table 5 shows a significant outcome ( $t=2.437, P<0.05)$, indicating that gender has positive effect on intention for self-employment with males having higher intention than their females' counterparts. The difference between gender group was observed in the test of homogeneity of variance which indicates the mean difference of each gender group of 0.03449 and 0.02432 for male and female respectively. Levene's test of equality of means shows F-value at 3.040 with p-value of 0.082 , which means equal variances in gender group were assumed. This finding support Ayuo \& Kubasu (2014), Dugassa 
(2012), Verheul et al., (2006) among others, and thus, contradictes' Mubbsher et al. (2011). As such, the initial null hypothesis should be rejected base on the t-test result and new hypothesis accepted as thus; there is significant difference in gender on intention for self-employment among postgraduate students of ATBU Bauchi.

The ANOVA result as presented in table 6 revealed no significant difference in age groups on intention for self-employment ( $F$ $=2.574, P>0.05)$. This means the result support the assumption of homogeneity of variance because equal variance was assumed in age groups. Therefore, null hypothesis which earlier states no significant difference should be accepted base on the ANOVAresult.

The decisions can be seen in table 7 below

Table 7: Summary of the result of hypotheses tested

\begin{tabular}{|c|l|c|c|}
\hline SN & Hypothesis Statement & Finding (P) & Decision \\
\hline 1. & $\begin{array}{l}\text { Age group has insignificant effect on intention for } \\
\text { self-employment among postgraduate students of } \\
\text { ATBU Bauchi. }\end{array}$ & 0.054 & Accepted \\
\hline 2. & $\begin{array}{l}\text { Gender has insignificant effect on intention for } \\
\text { self-employment among postgraduate students of } \\
\text { ATBU Bauchi }\end{array}$ & 0.015 & Rejected \\
\hline
\end{tabular}

Source: Field Survey (2017) 


\subsection{Conclusions and recommendations}

\subsection{Conclusion}

The conclusions of the study were drawn based on the objective and hypotheses of the study. From the demographic factors examined in this study, only gender has the propensity of igniting individual's intention for self-employment. Indeed, males were found to have higher intention than their female counterparts because entrepreneurial intention between the two gender categories varies. As such, attention of stakeholders concerned should focus more on gender (especially males) when designing supports and empowerment programmes for both prospective and potential graduateentrepreneurs in Nigeria. Finding of the study did not support Mubbsher et al. (2011), but is in line with Ayuo \& Kubasu (2014), Dugassa (2012), Verheul et al. (2006) among others.

\subsection{Recommendations}

Base on the finding of this research, the following recommendations were made to guide policy making:

i) Universities and agencies of government alike should not restrict their empowerment support programmes on self-employment to postgraduate students based on their age groups, because age was not a significant determinant of self-employment intention among postgraduate students.

ii) Emphasis on entrepreneurial training and intervention programmes should be directed to postgraduate students' base on gender, because gender significantly affects selfemployment intention with males demonstrating higher intention than their female's counterparts.

iii) Therefore, universities should complement government effort by designing policies and programmes that will financially empower and support postgraduate students on self-employment opportunities. In fact, the universities (e.g. ATBU) should replicate and establish an innovation-lab (just like its obtained in notable universities across the world i.e., Harvard, MIT, Kellog School of Management, etc.) where future studententrepreneurs can be trained early on skills acquisition programmes capable of leading them into self-employment. This will help reduce graduate's unemployment and bring about productivity for growth and development of the Nigerian economy.

\section{REFERENCES}

Agbim, K. C., Oriarewo, G. O., \& Owocho, M. (2013). Factors influencing entrepreneurial intentions among graduates of Nigerian tertiary institutions. International Journal of business and management invention, 2(4), 36-44.

Ajzen, I. (1991). The theory of planned behavior. Organizational behavior and human decision processes, 50(2), 179-211.

Amoor, S. S. (2008). Integrating entrepreneurship education into business education curriculum in Nigerian universities. Zaria Journal of Liberal Arts, 2(2), 1-12.

Ayuo, A., \& Kubasu, A. (2014). Theory of planned behaviour, contextual 
elements, demographic factors and entrepreneurial intentions of students in Kenya, European Journal of Business and Management (Online) Vol.6, No.15, 2014

Cortina, J. M. (1993). What is cronbach alpha? An examination of theory and applications. Journal of Applied Psychology, Vol. 78(1), 98-104.

Dandago, K. I., \& Muhammad, Y. M. (2014). Entrepreneurship development programmes and facilitation of youth employment in Kano State. Nigeria European Journal of Academic Research, 2(1), 17-30.

Dawson, C., Henley, A. \& Latreille, P. (2009). Why do Individuals Choose Selfemployment? IZA, Working Paper No. 397

Dugassa, T. G. (2012). Impact of entrepreneurship level of education on entrepreneurial intentions of business and engineering students in Ethiopia, African Journal of Economic and Management Studies, Vol. 3 (2), ISSN: 20400705

Fornell, C. \& Larcker, D. F. (1981). Evaluating structural equation models with unobservable variables and measurement error. Journal of Marketing Research, Vol. 18(1), 3950.

Ghasemi, A. \& Zahedias, S. (2012). Normality tests for statistical analysis: A Guide for Non-
Statisticians. International Journal of Endocrinology and Metabolism, Vol. 10(2)

Goetz, S. J., Fleming, D. A. \& Rupasingha, A. (2012). The economic impacts of self-employment, Journal of Agricultural and Applied Economics, Vol. 44 (3), 315-321.

Hair, J. J., Black, B., Barbin, B., Anderson, R. \& Tatham, R. (2006). Multivariate data analysis, $6^{\text {th }}$ edition, Upper Saddle River: NJ: Prentice-Hall

Hair, J. J., Black, W., Barbin, B. \& Anderson, R. (2010). Multivariate data analysis, $7^{\text {th }}$ edition, Upper Saddle River. NJ: Prentice-Hall

Helena, M. \& Maciera, C. (2009). The Determinants of self-employment, Unpublished Masters Dissertation, Industrial Engineering and Management, Instituto Suprior Tecnico, Universitade Tecnica de Lisboa

Ismail, M., Khalid, S. A., Othman, M., Jusoff, H. K., Rahman, N. A., Kassim, K. M. and Zain, R.S. (2009). Entrepreneurial intentions among Malaysian students, International Journal of Business and Management, Vol. 4(10), 54-60

Johnson, D. (2017). we'll improve access to varsity education - FG, Vanguard Newspaper

Johnson, D. (2016). what are demographic factors,

Kim, G. (2008). Entrepreneurship and selfemployment: The state-of-the-art 
and directions for future research, New England Journal of Entrepreneurship, Vol. 11(1), Article 5

Leong, C. K. (2008). Entrepreneurial intention: An empirical study among open university Malaysia students. Unpublished Project Paper. Submitted to Centre for Graduate Studies, Open University Malaysia.

Majogoro, K. \& Mgabo, M. R. (2012). Selfemployment intention among university students: Testing Ajzen's Theory of Planned Behavior. International Journal of Physical and Social Sciences, Vol.2(8),

Mubbsher, M. K., Ishfaq, A., Muhammad, M. N. \& Muhammad, R. (2011). the impact of personality traits on entrepreneurial intention of university students, Interdisci plinary Journal of Research in Business, Vol. 1(4), 51-57

Ogundele, M. O. Sofoluwe, A. O. \& Kayode D. J. (2012). Integrating entrepreneurship skills acquisition into national youths service corps (nysc) programme in Nigeria, Journal of Entrepreneurship and Management Vol. 1(3)

Okoye, L. J. (2016). Psychological predictors of entrepreneurial intention among Nigerian graduates, International Journal of Psychology and Counseling, Vol. 8(6), 73-80

Olawale, F. (2014). The entrepreneurial intention of undergraduate students in South Africa: The influences of entrepreneurship education and previous work experience Mediterranean Journal of Social Sciences, Vol. 5(7), 297-307

Pallant, J. (2001). SPSS survival manual: A step guide to data analysis for windows, version 10 . Victoria. Allen and Unwin

Perera, K. H., Jayarathna, L. C. H. \& Gunarathna, R. R. P. K. T. (2011). The entrepreneurial intention of undergraduates in Sri Lankan universities.

Polit, D. F. \& Beck, C. T. (2006). The content validity index: are you sure you know what's being reported? Critique and Recommendations, Research in Nursing and Health, 489-497

School of Postgraduate Studies, Abubakar Tafawa Balewa University, Bauchi, (2016). List of Students, (2015/2016)

Statistics Solutions, (Anonymous). Statistics solutions, advancement through unity.

Tabachnick, B. G., \& Fidell, L. S. (2007). Using multivariate statistics, $5^{\text {th }}$ edition. Boston: Peason. Allyn and Bacon

Verheul, I., Thuirk, R. \& Grilo, I. (2006). Determinants of Self-employment preference and realization of women and men in Europe and the United States, Scientific Analysis of Entrepreneurship and SME's, EIM Business and Policy Research. 
Vijeyan, S., ShishiKumar, P., Abd Kadir, O., \& Zahir, O. (2015). Impact of psychological traits, entrepreneurial education and culture in determining entrepreneurial intention among pre-university students in Malaysia, American Journal of Economics, Vol. 5(2), 163-167

World Trade Organization, (1996).
Participation of developing countries in world trade: Overview of major trends and underlying factors, WT/COMTD/W/15, Com mittee on Trade and Development Yamane, T. (1967). How to determine sample size? 